\title{
Erratum to: Cytomegalovirus esophagitis precipitated with immunosuppression in elderly giant cell arteritis patients
}

\author{
Sibel Akın - Fatih Tufan • Gülistan Bahat • \\ Bülent Saka • Nilgün Erten • Mehmet Akif Karan
}

Published online: 25 April 2013

(C) Springer International Publishing Switzerland 2013

\section{Erratum to: Aging Clin Exp Res}

DOI 10.1007/s40520-013-0019-8

An error has occurred in legend of Fig. 1.

The correct legend is:

Esophagoscopy showing glycogenic acanthosis and ulcers on oropharynx and esophagus

The online version of the original article can be found under doi:10.1007/s40520-013-0019-8.

S. Akın $(\bowtie) \cdot$ F. Tufan · G. Bahat · M. A. Karan

Division of Geriatrics, Department of Internal Medicine,

Istanbul School of Medicine, Istanbul University,

Capa, 34093 Istanbul, Turkey

e-mail: sibelyanmaz@gmail.com

B. Saka $\cdot$ N. Erten

Department of Internal Medicine, Istanbul School of Medicine,

Istanbul University, Capa, 34093 Istanbul, Turkey 